\title{
Extracellular vesicles carry cellulases in the industrial fungus Trichoderma reesei
}

\author{
Renato Graciano de Paula', Amanda Cristina Campos Antoniêto' ', Karoline Maria Vieira Nogueira', \\ Liliane Fraga Costa Ribeiro', Marina Campos Rocha², Iran Malavazi², Fausto Almeida \\ and Roberto Nascimento Silva ${ }^{1 *}$ (1)
}

\begin{abstract}
Background: Trichoderma reesei is the most important industrial producer of lignocellulolytic enzymes. These enzymes play an important role in biomass degradation leading to novel applications of this fungus in the biotechnology industry, specifically biofuel production. The secretory pathway of fungi is responsible for transporting proteins addressed to different cellular locations involving some cellular endomembrane systems. Although protein secretion is an extremely efficient process in T. reesei, the mechanisms underlying protein secretion have remained largely uncharacterized in this organism.

Results: Here, we report for the first time the isolation and characterization of T. reesei extracellular vesicles (EVs). Using proteomic analysis under cellulose culture condition, we have confidently identified 188 vesicular proteins belonging to different functional categories. Also, we characterized EVs production using transmission electron microscopy in combination with light scattering analysis. Biochemical assays revealed that T. reesei extracellular vesicles have an enrichment of filter paper (FPase) and $\beta$-glucosidase activities in purified vesicles from 24, 72 and 96, and 72 and $96 \mathrm{~h}$, respectively. Furthermore, our results showed that there is a slight enrichment of small RNAs inside the vesicles after $96 \mathrm{~h}$ and $120 \mathrm{~h}$, and presence of hsp proteins inside the vesicles purified from T. reesei grown in the presence of cellulose.
\end{abstract}

Conclusions: This work points to important insights into a better understanding of the cellular mechanisms underlying the regulation of cellulolytic enzyme secretion in this fungus.

Keywords: Trichoderma reesei, Extracellular vesicles, Cellulases, Secretion, Proteome

\section{Background}

Trichoderma reesei is one of the main producers of cellulolytic and xylanolytic enzymes, being the most studied fungus involved with lignocellulosic degradation [1-4]. It has the ability to colonize a wide range of habitats and is able to fully break down different types of biomass by secreting a range of enzymes and metabolites [5-9]. In $T$. reesei, the gene expression and secretion of enzymes are directly dependent on the different chemical signals produced from diverse substrates. This feature provides the

\footnotetext{
*Correspondence: rsilva@fmrp.usp.br

1 Department of Biochemistry and Immunology, Ribeirao Preto Medical School, University of Sao Paulo, Ribeirao Preto, São Paulo 14049-900, Brazil Full list of author information is available at the end of the article
}

ability to grow in a wide range of carbon sources and the production a variable range of cellulases [10].

The natural ability to produce and secrete large amounts of protein makes $T$. reesei an interesting host for production of heterologous proteins used in various different industrial applications [11]. In this fungus, the secretory pathway is an important route of cell communication with the environment. It is responsible for secreting molecules to send distinct signals to other cells, hydrolytic enzymes to obtain nutrients and respond or adapt to changes in the microenvironment [12]. Regarding this, different organelles are responsible for the biosynthesis, assembly, folding and modifications of proteins in the secretory pathways [13]. In process of proteins synthesis, proteins are synthesized in the ribosomes and 
then, are transported through the rough endoplasmic reticulum (ER), and thus, the polypeptides are translocated into the lumen of this organelle [14]. Once in the ER lumen, the polypeptides may undergo various posttranslational modifications [15].

After trafficking inside the ER, the proteins are directed from ER to the Golgi complex, and this process involves packaging proteins in coat protein complex II (COPII)coated vesicles $[16,17]$. In $T$. reesei, genomic analysis has indicated the presence of the gene encoding COPIIcoated vesicles for the anterograde transport from ER to Golgi complex [12, 18]. Right after proteins are delivered to the Golgi complex they undergo proteolytic processing to generate mature polypeptides [19]. Finally, in the last step of the secretory pathway, the protein needs to be transported from Golgi complex to the plasma membrane, and this process involves vesicle formation. Extracellular vesicles (EVs) are defined as a heterogeneous group of cell-derived membranous structures comprising exosomes and microvesicles, which originate from the endosomal system or which are shed from the plasma membrane, respectively [20].

During this process of vesicles formation, different regulatory proteins have an essential role. In this scenario, GTPase Arf1 has a crucial participation in the formation of the exomer, which is responsible to coat vesicles designated to the plasma membrane [21], and GTPases Sec4, Rho1, Rho3, and Cdc42 need to be activated to promote the final docking event allowing the coated-vesicles reach the plasma membrane [22, 23]. Finally, SNARE proteins such as Sec9, Snc1, Sso1, and Sso2 are equally important in vesicle and plasma membrane fusion [24]. Regarding, in T. reesei, sncl, ssol, and sso2 have been identified in subapical areas of the hyphal plasma membrane [25].

Using bioinformatic analysis of signal sequences, Druzhinina et al. [26] suggested that the majority of the secreted proteins in $T$. reesei are hydrolases, small cysteine-rich proteins, proteases, lipases, nucleases, oxidases, and phosphatases. Furthermore, beyond the secretion of holocellulolytic enzymes, this fungus has the ability to secrete laccases, glyoxal oxidase, peroxin, peroxidase, catalase, glutathione transferase, cytochrome oxidase and cytochrome peroxidase [27]. Regarding holocellulolytic enzymes, the cellobiohydrolases (Cel7a and Cel6a) and the endoglucanases (Cel7b and Cel5a) are the most common cellulolytic enzymes identified in the secretome of this fungus $[28,29]$. Though all this knowledge about cellulase secretion on $T$. reesei, there is a series of questions regarding the secretory pathway of cellulases that remain unanswered, including (1) How does cellulose trigger the induction of cellulases? (2) What are the intracellular signaling pathways? (3) What are the subcellular locations of cellulases? So, here we showed for the first time the identification and characterization of extracellular vesicles in $T$. reesei along with the proteomic content analysis of extracellular vesicles (EVs) in the presence of cellulose.

\section{Methods}

\section{Fungal strain and growth conditions}

The Trichoderma reesei strain QM6a $\Delta$ tmus53 5 pyr4 [30] used in this study was obtained from the Institute of Chemical Engineering \& Technical Biosciences of Vienna University of Technology, TU Vienna, Austria. The strain was maintained at $4{ }^{\circ} \mathrm{C}$ on MEX medium [malt extract $3 \%(\mathrm{w} / \mathrm{v})$ and agar-agar $2 \%(\mathrm{w} / \mathrm{v})]$, which was supplemented with $5 \mathrm{mM}$ uridine in the case of the pyr4 deletion strain. For all experiments, a spore suspension of QM6a $\Delta$ tmus $53 \Delta$ pyr4 strain containing $10^{6}$ cells $/ \mathrm{mL}$ was precultured into $200 \mathrm{~mL}$ of Mandels-Andreotti medium [31] supplemented with glycerol $1 \%(\mathrm{w} / \mathrm{v})$ for $24 \mathrm{~h}$ and then transferred to a $200 \mathrm{~mL}$ of fresh Mandels-Andreotti medium containing $1 \%$ of Avicel [32, 33]. The cultures were incubated on an orbital shaker $(200 \mathrm{rpm})$ at $30{ }^{\circ} \mathrm{C}$ for $24,48,72,96$ or $120 \mathrm{~h}$. For glucose experiments, the fungus was grown in $2 \%$ glucose for $24 \mathrm{~h}$. The resulting culture supernatant was collected by filtration and used for EVs isolation. All experiments were performed in three biological replicates.

\section{Vesicles isolation and characterization}

Extracellular vesicles were isolated as previously described for other fungi [34-37], with slight modifications. T. reesei fungal cells were separated from culture supernatants by centrifugation at $4000 \times g$ for $30 \mathrm{~min}$ at $4{ }^{\circ} \mathrm{C}$, and the pellets discarded. The obtained supernatants were concentrated approximately 50-fold through polystyrene membranes using Amicon ultrafiltration system (cutoff, $100 \mathrm{kDa}$ ). The resulting supernatant was centrifuged at $60,000 \times g$ for $1 \mathrm{~h}$ at $4{ }^{\circ} \mathrm{C}$. The supernatants were discarded, and the pellets washed twice with $0.1 \mathrm{M}$ phosphate-buffered saline (PBS) by sequential resuspension and centrifuging them at $60,000 \times g$ for $1 \mathrm{~h}$ at $4{ }^{\circ} \mathrm{C}$.

The size-distribution and quantification of extracellular vesicles preparations were measured by nanoparticle-tracking analysis (NTA) using a NanoSight NS300 (Malvern Instruments, Malvern, UK) equipped with fast video capture and particle-tracking software, as previously described [38]. Purified vesicles from T. reesei were $20 \times$ diluted into $1 \mathrm{~mL}$ of PBS, and each sample was then injected into a NanoSight sample cubicle. The measurements were obtained in triplicate and analyzed using NanoSight software (version 3.2.16). The data on the sizes of extracellular vesicles from $T$. reese $i$ are expressed as the calculated mean \pm SD of size distribution. 


\section{Transmission electron microscopy (TEM)}

Mycelia aliquots withdrawn from QM6a $\Delta$ tmus $53 \Delta$ pyr4 at $24,48,72,96$ and $120 \mathrm{~h}$ during culture in the presence of Avicel, and glucose and glycerol at $24 \mathrm{~h}$ were centrifuged at $6000 \times g$ and immediately fixed in $0.1 \mathrm{M}$ sodium phosphate buffer $(\mathrm{pH} 7.4)$ containing $2.5 \%(\mathrm{v} / \mathrm{v})$ of glutaraldehyde and $2 \%(\mathrm{w} / \mathrm{v})$ of paraformaldehyde for $24 \mathrm{~h}$ at $4{ }^{\circ} \mathrm{C}$. Samples were encapsulated in agar $(2 \%$ $\mathrm{w} / \mathrm{v})$ and subjected to fixation $\left(1 \% \mathrm{OsO}_{4}\right)$, contrasting (1\% uranyl acetate), ethanol dehydration, and a twostep infiltration process with Spurr resin (Electron Microscopy Sciences) of $16 \mathrm{~h}$ and $3 \mathrm{~h}$ at room temperature (RT). Additional infiltration was provided under vacuum at RT before embedment in BEEM capsules (Electron Microscopy Sciences) and polymerization at $60{ }^{\circ} \mathrm{C}$ for $72 \mathrm{~h}$. Semithin $(0.5-\mu \mathrm{m})$ survey sections were stained with toluidine blue to identify the areas of best cell density. Ultrathin sections $(60 \mathrm{~nm})$ were prepared and stained again with uranyl acetate (1\%) and lead citrate (2\%). Transmission electron microscopy (TEM) images were obtained using a Philips CM-200 electron microscope at an acceleration voltage of $120 \mathrm{kV}$ using a MegaView3 camera and iTEM 5.0 software (Olympus Soft Imaging Solutions $\mathrm{GmbH}$ ).

\section{Proteomic analysis}

The vesicles samples were sonicated to release protein content. Subsequently, total protein was quantified using the Bradford method and concentrated using Amicon Ultra $0.5 \mathrm{~mL}$ centrifugal filters (MWCO $3 \mathrm{kDa}$ ) (Millipore, Burlington, Massachusetts, EUA). Proteins were suspended in $250 \mu \mathrm{L} 100 \mathrm{mM} \mathrm{NH} \mathrm{HCO}_{3}$ containing $8 \mathrm{M}$ urea and reduced with $5 \mathrm{mM}$ dithiothreitol $37^{\circ} \mathrm{C}$ for $1 \mathrm{~h}$. Reduced thiol groups were alkylated with $100 \mathrm{mM}$ $\mathrm{NH}_{4} \mathrm{HCO}_{3}$ containing $8 \mathrm{M}$ urea and $50 \mathrm{mM}$ iodoacetamide for $1 \mathrm{~h}$ at RT in the dark. Protein digestion was carried out by incubating the samples with trypsin $20 \mathrm{ng} / \mu \mathrm{L}$ (Promega; Madison, WI, USA; 1:50; w/w) overnight at $37{ }^{\circ} \mathrm{C}$. After quenching the reaction with trifluoroacetic acid (TFA) to a final concentration of 1\% TFA, the peptide mixture was desalted, concentrated on ziptip (Millipore) [39]. Recovered peptides were dissolved in $0.1 \%$ formic acid and then subjected to nanoLC-MS/MS analysis, using Bruker Maxis Q-TOF coupled to a nanoLC (NanoAcquity Waters). The peptides were loaded onto a nanoAcquity UPLC ${ }^{\circledR}$ 2G-V/MTrap $5 \mu$ m Symmetry ${ }^{\circledR}$ C18 $180 \mu \mathrm{m} \times 20 \mathrm{~mm}$ precolumn (Waters). The elution was made with a linear gradient of $2-85 \%$ acetonitrile in $0.1 \%$ aqueous solution of formic acid. The gradient was performed over 85 min using nanoAcquity UPLC ${ }^{\circledR} 1.7 \mu \mathrm{m}$ BEH130 $100 \mu \mathrm{m} \times 100 \mathrm{~mm}$ (Waters) column at a flow rate of $0.3 \mu \mathrm{L} / \mathrm{min}$.
Raw files were converted to .dta files for a Mascot database (Mascot software; Matrix Science; Boston, MA, USA) search. A database containing $T$. reesei protein sequences was searched using Mascot software (version 2.3) for protein identification. Moreover, acquired raw data were converted to mzXML and automatically processed by an in-house installation of Labkey Server v12, using the X!Tandem search algorithm [40]. The minimum criterion for peptide matching was performed using a Peptide Prophet [41] score greater than 0.8. Peptides that met these criteria were further grouped to protein sequences using the Protein Prophet [42] algorithm and only proteins with an error rate of $5 \%$ or less and two peptides sequences identified were considered as valid identifications. A combined list of proteins identified in all replicates $(n=3)$ and MASCOT-LabKey Server searches were condensed to remove redundant IDs such as orthologous sequences, redundant database entries, and indistinguishable isoforms based on observed peptide coverage.

\section{RNA isolation}

RNA was extracted from lyophilized vesicles samples using the TRIzol ${ }^{\circledR}$ RNA kit (Invitrogen Life Technologies, CA, USA), according to the manufacturer's instructions. The RNA concentration was determined by spectrophotometric OD at 260/280, and the RNA integrity was verified by both the Agilent 2100 Bioanalyzer.

\section{Enzyme activity assays}

The vesicles samples were sonicated to release protein content. Subsequently, $\beta$-glucosidase and filter paper (FPase) activities were assayed in the isolated vesicles or supernatant culture by the ability to hydrolyze pNPG ( $p$-nitrophenyl- $\beta$-D-glucopyranoside) and filter paper, respectively, following published protocols [43-46]. For $\beta$-glucosidase activity, the reaction consisted of $10 \mu \mathrm{L}$ of isolated vesicle suspension or $10 \mu \mathrm{L}$ supernatant, $50 \mu \mathrm{L}$ of $50 \mathrm{mM}$ sodium acetate buffer and $40 \mu \mathrm{L}$ of $5 \mathrm{mM}$ of a specific substrate. The reactions were incubated at $50{ }^{\circ} \mathrm{C}$ for $15 \mathrm{~min}$ ( $\beta$-glucosidase), followed by the addition of $100 \mu \mathrm{L}$ of $1 \mathrm{M}$ sodium carbonate [47]. The enzymatic activities were performed in a 96-well microplate, and absorbance was read at $405 \mathrm{~nm}$ using the $\mathrm{xMark}^{\mathrm{TM}}$ Microplate Spectrophotometer (Bio-Rad, CA, USA). Filter paper activity (FPase) was determined by an enzymatic reaction employing Whatman filter paper no. $1,30 \mu \mathrm{L}$ of isolated vesicle suspension or $30 \mu \mathrm{L}$ of supernatant, and $30 \mu \mathrm{L}$ of $100 \mathrm{mM}$ citrate buffer $\mathrm{pH} 5.0$ [47]. The reactions were incubated at $50{ }^{\circ} \mathrm{C}$ for $18 \mathrm{~h}$. Next, $60 \mu \mathrm{L}$ of dinitrosalicylic acid (DNS) was add to the reaction, which was then heated at $95{ }^{\circ} \mathrm{C}$ for $5 \mathrm{~min}$. The FPase activity was also assayed in a 96-well microplate, and absorbance was 
read at $540 \mathrm{~nm}$ using the $\mathrm{xMark}^{\mathrm{TM}}$ Microplate Spectrophotometer (Bio-Rad, CA, USA). One enzyme unit was defined as the amount of enzyme capable of liberating $1 \mu \mathrm{mol}$ of reducing sugar per minute [43].

\section{Results}

\section{Identification and characterization of $T$. reesei extracellular} vesicles

This work shows the first characterization of extracellular vesicles (EVs) of T. reesei (Fig. 1). Our results showed that $T$. reesei was able to produce a significant number of extracellular vesicles from $24 \mathrm{~h}$ of induction in the presence cellulose exhibiting the highest level of production at $96 \mathrm{~h}$ (Fig. 1a, c). The majority of the EVs population displayed diameter size ranging from 100 to $200 \mathrm{~nm}$, with a mean size of $144 \mathrm{~nm}$ (Fig. 1b and Additional file 1: Fig. S1). Figure 1a-c shows a representative view of the different vesicles sizes and location obtained by supernatant purification. The mean concentration of particles in the supernatants from 24, 48, 72, 96 and 120 h were $4.61 \times 10^{9}, 2.83 \times 10^{10}, 7.89 \times 10^{9}, 4.11 \times 10^{10}$ and $1.09 \times 10^{10}$ particles $/ \mathrm{mL}$, respectively. As expected, no particles were found in the medium alone (negative control; data not shown). Also, to confirm that the vesicles originated from live cells and not from membranes released from dead cells, we analyzed a control preparation from each time of culture supernatants of $T$. reesei mycelia that had been killed by heating at $70{ }^{\circ} \mathrm{C}$ for $24 \mathrm{~h}$ and then inoculated in minimal medium and cultivated in parallel under the same conditions as those used for the live cells. Our NTA results demonstrated that no nanoparticles were generated from the heat-killed T. reesei mycelia (data not shown).

Interestingly, our analysis demonstrated the growth of $T$. reesei in the presence of cellulose generate a higher number of EVs than compared to the repressive or neutral carbon sources glucose or glycerol, respectively (Additional file 1: Fig. S3c). As shown in this figure, in the presence of glucose and glycerol we have a few numbers of EVs. The NTA analysis showed that the EVs purified from glycerol are smaller than glucose and cellulose culture, exhibiting a size of $108 \mathrm{~nm}, 153 \mathrm{~nm}$, and $144 \mathrm{~nm}$, respectively (Additional file 1: Fig. S3a and b). These results suggest that there is an unknown mechanism involving EVs production in $T$. reesei in the presence of cellulose.

Transmission electron microscopy analysis of vesicles from mycelium revealed a large amount of EVs in samples
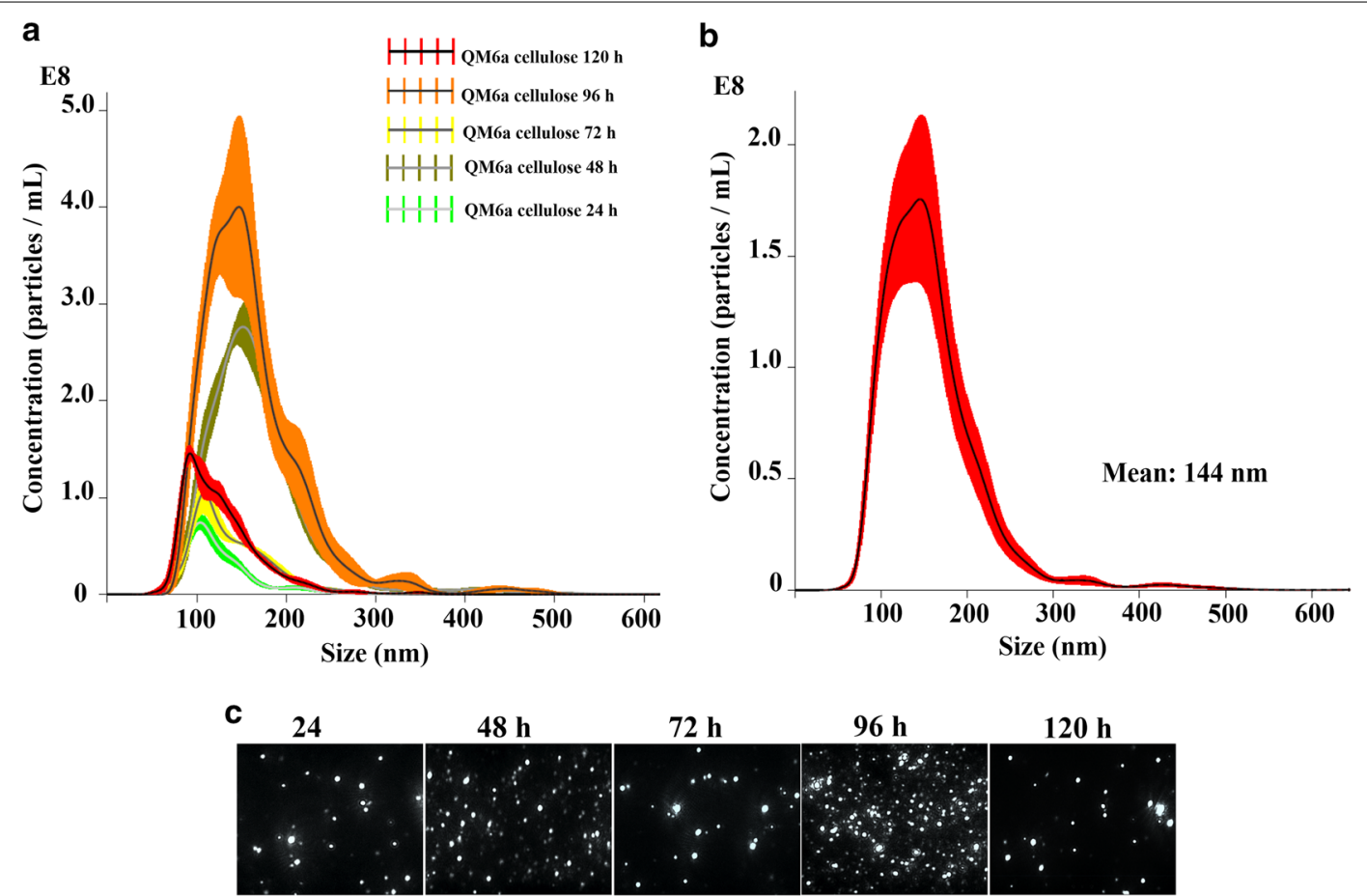

Fig. 1 Nanoparticle-tracking analysis (NTA) of extracellular vesicles (EVs) produced by T. reesei. a Histogram showing the EV particle-size distribution (EVs $\times 10^{8} / \mathrm{mL}$ vs size in nanometers) from the cellulose-supernatant culture at $24,48,72,96$ and $120 \mathrm{~h}$ post-induction in the presence of cellulose. b Histogram showing the calculated mean \pm SD of size distribution by NTA analysis of purified T. reesei EVs. c Screenshots from video recorded using NanoSight NS300, showing the distribution of EVs from the cellulose-supernatant culture at 24, 48,72, 96 and $120 \mathrm{~h}$. These results are based on three replicates of three independent experiments 

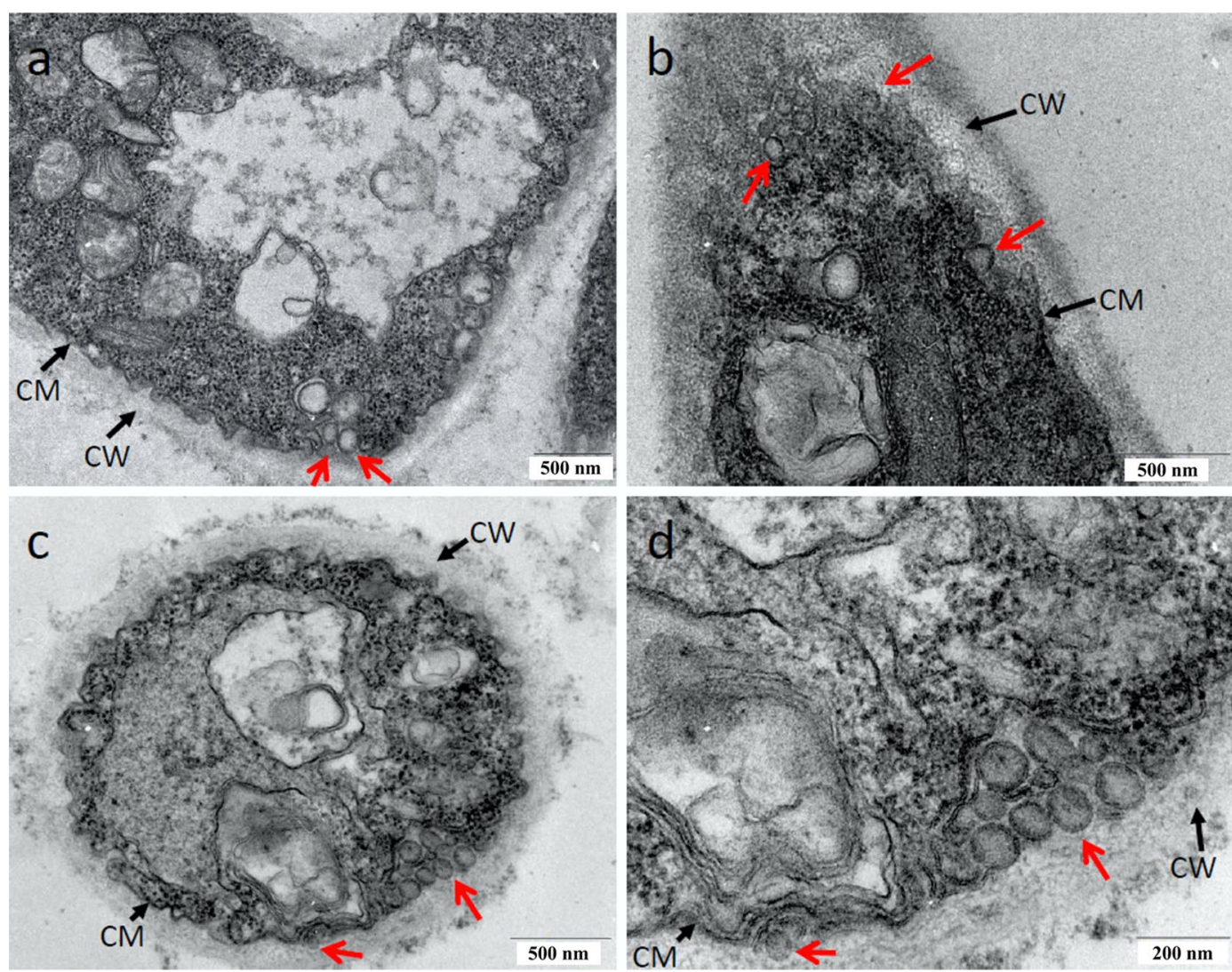

Fig. 2 TEM analyses of vesicles in Trichoderma reesei mycelium cells. a-d The occurrence of vesicles in association with the cytoplasmic membrane and cell wall is evident after growth for $48 \mathrm{~h}$ in the presence of cellulose. Black arrows indicate the cell wall (CW) and cell membrane (CM). Red arrows indicate the T. reesei vesicles. Bars, $500 \mathrm{~nm}(\mathbf{a}-\mathbf{c})$ and $200 \mathrm{~nm}$ (d)

isolated from T. reesei cellulose culture (Fig. 2). The vesicles seem to be mainly associated with the cytoplasmic membrane (CM) (Fig. 2a, c) and some of them were visualized in association with the cell wall (CW) (Fig. 2b, d). Similarly, we also able to identify vesicles from mycelium cultivated in the presence of glycerol and glucose (Additional file 1: Fig. S4). However, our results showed that mycelia isolated from these conditions have a small number of EVs when compared to cellulose (Fig. 2). These results suggest that vesicles of $T$. reesei are produced in the presence of cellulose, glucose, and glycerol and are secreted via the canonical secretory pathway involving passage through the cell wall, in turn, releasing extracellular proteins to the extracellular space, thus providing additional evidence for the existence of an extracellular vesicular transport mechanism.

\section{Proteomic analysis}

In order to analyze the effects of cellulases secretion in response to cellulose, we identified the protein content of the EVs. Our report contains the first EVs proteomic analysis of $T$. reesei during growth in the presence of an inductive carbon source. Accordingly, EVs were isolated from cell-free culture supernatants from T. reesei and analyzed by LC-MS/MS. A total of 188 proteins were identified in a time-course experiment $(24 \mathrm{~h}$ to $120 \mathrm{~h}$ ) of cultivation in the presence of cellulose (Additional file 2). Among these proteins, 33 of them were identified exclusively in vesicles originating from cellfree culture supernatant induction at $24 \mathrm{~h}, 14$ found exclusively at $48 \mathrm{~h}, 49$ shown exclusively at $72 \mathrm{~h}, 37$ found exclusively at $96 \mathrm{~h}$ and 29 identified exclusively at $120 \mathrm{~h}$ in the presence of cellulose (Fig. 3a). These results strongly suggest dynamics in vesicle content production during the cellulose utilization by the fungus. Consistently, a small number of proteins were commonly identified among the conditions examined and only one protein, encoding an RNA-binding protein involved with rRNA biogenesis (ID 78062) was identified in all time points (Fig. 3a). Furthermore, our data showed that 12 proteins with chaperones-related activity, which are involved in folding protein, were identified inside the $T$. reesei EVs (Table 1). These results suggest that protein folding, stability, and modifications to reach 

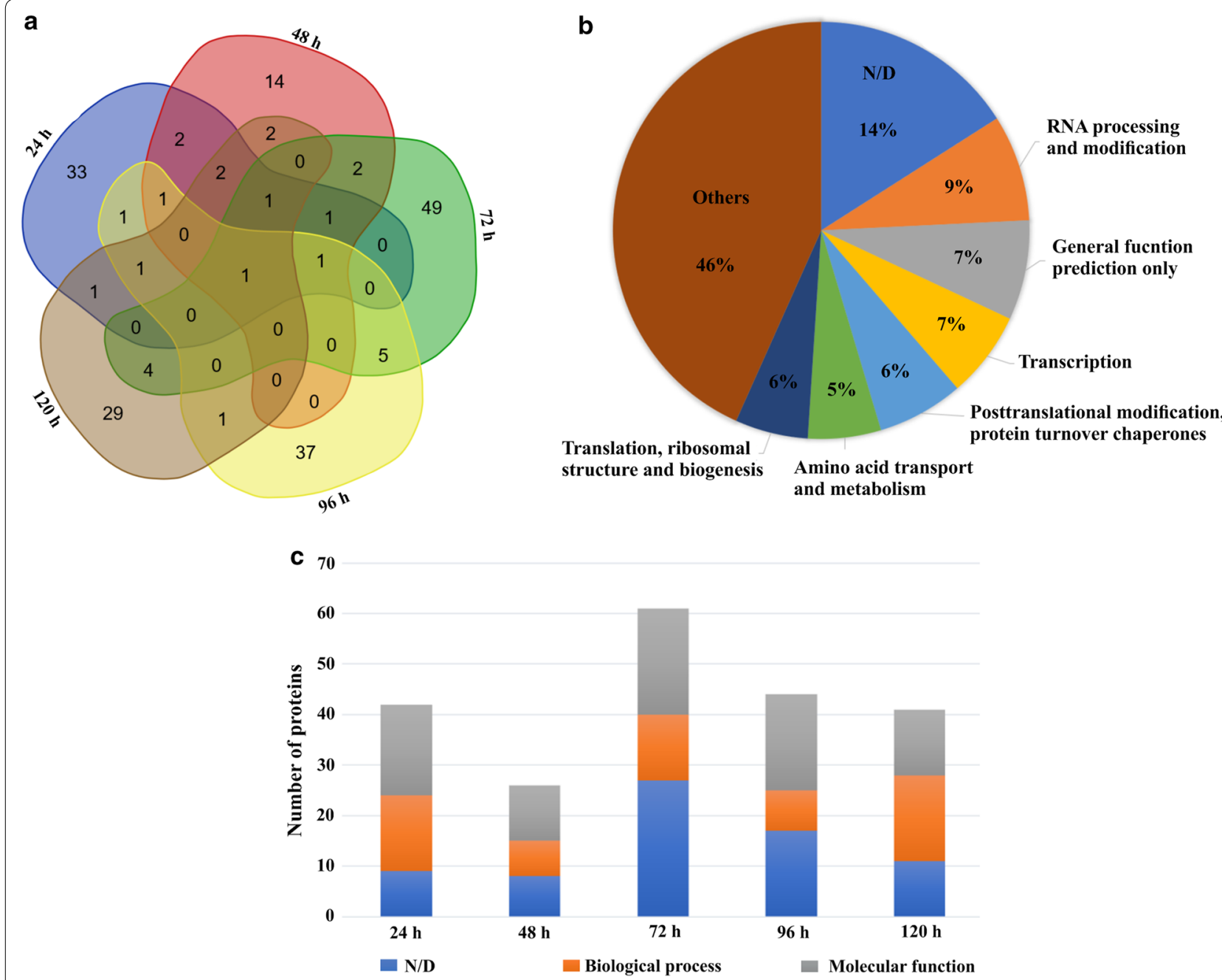

Fig. 3 Proteomic analysis of T. reesei EVs. a Expression pattern of the proteins identified in T. reesei EVs at 24, 48, 72, 96 and $120 \mathrm{~h}$ in the presence of cellulose. Venn diagram clustering was designed using Bioinformatics \& Evolutionary Genomics tools (http://bioinformatics.psb.ugent.be/webtools/ Venn/). $\mathbf{b}$ KOG term of 188 proteins identified in T. reesei EVs. c Molecular function and biological process of proteins identified at 24, 48, 72, 96 and $120 \mathrm{~h}$ in the presence of cellulose. The proteins are classified in terms of Gene Ontology (GO) being molecular function related to proteins features, such as binding or catalysis, and finally, biological process, classified the proteins according to the processes that it involved. These results are based on three replicates of three independent experiments

native structure could be an active process inside $T$. reesei EVs.

The vesicular proteins were categorized by the biological process using KOG annotation and was demonstrated that they are involved (Fig. 3b) with six principal groups, including, 9\% RNA processing-related proteins, 7\% with general functions, $7 \%$ transcription-related proteins, $6 \%$ of proteins associated to posttranslational modification, 5\% involved with amino acid transport and metabolism and 6\% translation-related proteins. Regarding the remaining proteins, including CAZymes, $46 \%$ were related to other functions and $14 \%$ are still uncharacterized. Again, our time-course categorization by molecular function and biological process showed that the functional composition of $T$. reese $i$ vesicles content is very diverse (Fig. 3c). These results suggest that the protein content of the vesicles is highly variable, and possibly correlated with different growth stages of the fungus during cultivation in presence of cellulose.

\section{CAZy-related proteins are enriched inside T. reesei EVs} Interestingly, our proteomic analysis showed that there are some CAZy-related proteins inside de T. reesei EVs after growth in the presence of cellulose (Table 2). In this respect, we identified nine CAZYmes inside the EVs including, a glycoside hydrolase (GH) GH64 
Table 1 Chaperone-like proteins identified inside T. reesei extracellular vesicles

\begin{tabular}{|c|c|c|c|c|}
\hline Protein ID & Description & GO & KOG & Identification time \\
\hline 119924 & $\begin{array}{l}\text { Hsp70 nucleotide exchange factor } \\
\text { FES1, putative }\end{array}$ & \#N/D & $\begin{array}{l}\text { Posttranslational modification, pro- } \\
\text { tein turnover, chaperones }\end{array}$ & $24 \mathrm{~h}$ \\
\hline 119731 & $\begin{array}{l}\text { Heat shock protein hsp60 mitochon- } \\
\text { drial precursor protein }\end{array}$ & Cellular protein metabolism & $\begin{array}{l}\text { Posttranslational modification, pro- } \\
\text { tein turnover, chaperones }\end{array}$ & $24 \mathrm{~h}, 48 \mathrm{~h}, 72 \mathrm{~h}$ and $120 \mathrm{~h}$ \\
\hline 66183 & Peptidase_Serine carboxypeptidase & Proteolysis and peptidolysis & $\begin{array}{l}\text { Posttranslational modification, pro- } \\
\text { tein turnover, chaperones }\end{array}$ & $24 \mathrm{~h}$ \\
\hline 73678 & $\begin{array}{l}\text { Calnexin, high identity with A. niger } \\
\text { ClxA }\end{array}$ & Calcium ion binding & $\begin{array}{l}\text { Posttranslational modification, pro- } \\
\text { tein turnover, chaperones }\end{array}$ & $24 \mathrm{~h}$ \\
\hline 36822 & Unknown protein & Catalytic activity & $\begin{array}{l}\text { Posttranslational modification, pro- } \\
\text { tein turnover, chaperones }\end{array}$ & $24 \mathrm{~h}$ \\
\hline 48001 & Unknown protein with DnaJ domain & Unfolded protein binding & $\begin{array}{l}\text { Posttranslational modification, pro- } \\
\text { tein turnover, chaperones }\end{array}$ & $48 \mathrm{~h}$ \\
\hline 107011 & Unknown protein & Unfolded protein binding & $\begin{array}{l}\text { Posttranslational modification, pro- } \\
\text { tein turnover, chaperones }\end{array}$ & $72 \mathrm{~h}$ \\
\hline 104390 & Glutathione S-transferase & Glutathione transferase activity & $\begin{array}{l}\text { Posttranslational modification, pro- } \\
\text { tein turnover, chaperones }\end{array}$ & $72 \mathrm{~h}$ \\
\hline 124282 & $\begin{array}{l}\text { Unknown protein, SET and MYND } \\
\text { domain }\end{array}$ & \#N/D & $\begin{array}{l}\text { Posttranslational modification, pro- } \\
\text { tein turnover, chaperones }\end{array}$ & $96 \mathrm{~h}$ \\
\hline 21444 & Unknown protein & $\begin{array}{l}\text { Hydrogen-transporting ATPase } \\
\text { activity, rotational mecha- } \\
\text { nism }\end{array}$ & $\begin{array}{l}\text { Posttranslational modification, pro- } \\
\text { tein turnover, chaperones }\end{array}$ & $120 \mathrm{~h}$ \\
\hline 21461 & ATP-dependent protease La, putative & ATP binding & $\begin{array}{l}\text { Posttranslational modification, pro- } \\
\text { tein turnover, chaperones }\end{array}$ & $120 \mathrm{~h}$ \\
\hline 123922 & Peptidyl-prolyl isomerase & Protein folding & $\begin{array}{l}\text { Posttranslational modification, pro- } \\
\text { tein turnover, chaperones }\end{array}$ & $72 \mathrm{~h}$ and $96 \mathrm{~h}$ \\
\hline
\end{tabular}

Table 2 CAZy-related proteins identified inside $T$. reesei extracellular vesicles

\begin{tabular}{|c|c|c|c|c|}
\hline Protein ID & Description & GO & KOG & Identification time \\
\hline 124175 & GH64 endo-1,3- $\beta$-glucanase & \#N/D & \#N/D & $72 \mathrm{~h}$ and $120 \mathrm{~h}$ \\
\hline 124016 & GH36 a-galactosidase AGL2 & Carbohydrate metabolism & \#N/D & $96 \mathrm{~h}$ and $120 \mathrm{~h}$ \\
\hline 121746 & $\begin{array}{l}\text { Glycoside hydrolase family } 55 \text { (candidate } \\
\text { exo-1,3-b-glucanase) }\end{array}$ & Carbohydrate metabolism & \#N/D & $72 \mathrm{~h}$ and $120 \mathrm{~h}$ \\
\hline 123649 & $\beta-1,6-N$-Acetylglucosaminyltransferase & $\begin{array}{l}\text { Carbohydrate transport } \\
\text { and metabolism }\end{array}$ & Carbohydrate transport and metabolism & $72 \mathrm{~h}$ and $96 \mathrm{~h}$ \\
\hline 123538 & $\begin{array}{l}\text { Candidate membrane-bound } \beta-1,3- \\
\text { glucanosyltransglycosylase (GH72 } \beta-1 \\
\text { 3-glucanosyltransferase) }\end{array}$ & \#N/D & \#N/D & $48 \mathrm{~h}$ \\
\hline 80833 & GH18 chitinase Chi18-5 & Hydrolase activity & Carbohydrate transport and metabolism & $72 \mathrm{~h}$ \\
\hline 21725 & GH20 exochitinase (nag1) & Carbohydrate metabolism & Carbohydrate transport and metabolism & $120 \mathrm{~h}$ \\
\hline 123989 & Glycoside hydrolase family 7 (cel7a) & Carbohydrate metabolism & Function unknown & $48 \mathrm{~h}$ and $120 \mathrm{~h}$ \\
\hline 112271 & GT2 chitin synthase chs3 & Chitin biosynthesis & Cell wall/membrane/envelope biogenesis & $72 \mathrm{~h}$ \\
\hline
\end{tabular}

endo-1,3- $\beta$-glucanase, a GH36 $\alpha$-galactosidase (AGL2), a GH55 candidate exo-1,3- $\beta$-glucanase, two glycosyltransferases $\quad(\beta-1,6, N$-acetylglucosaminyltransferase), a GH72 (candidate membrane-bound $\beta-1,3-$ glucanosyltransglycosylase), and three proteins related to chitinolytic enzyme machinery of fungi (GH18 chitinase Chi18-5, a GH20 exochitinase nag1-possibly involved with mycoparasitism and GT2 chitin synthase chs3-involved with chitin biosynthesis). Finally, we demonstrated that the cellobiohydrolase Cel7a belonging to GH7 family, the dominant enzyme of the T. reesei cellulolytic complex was also identified in the EVs cellulose proteome.

In addition, enzymatic assay revealed that the specific filter paper activity (FPase) was higher in purified EVs from 24, 72, and $96 \mathrm{~h}$ of cultivation in presence 


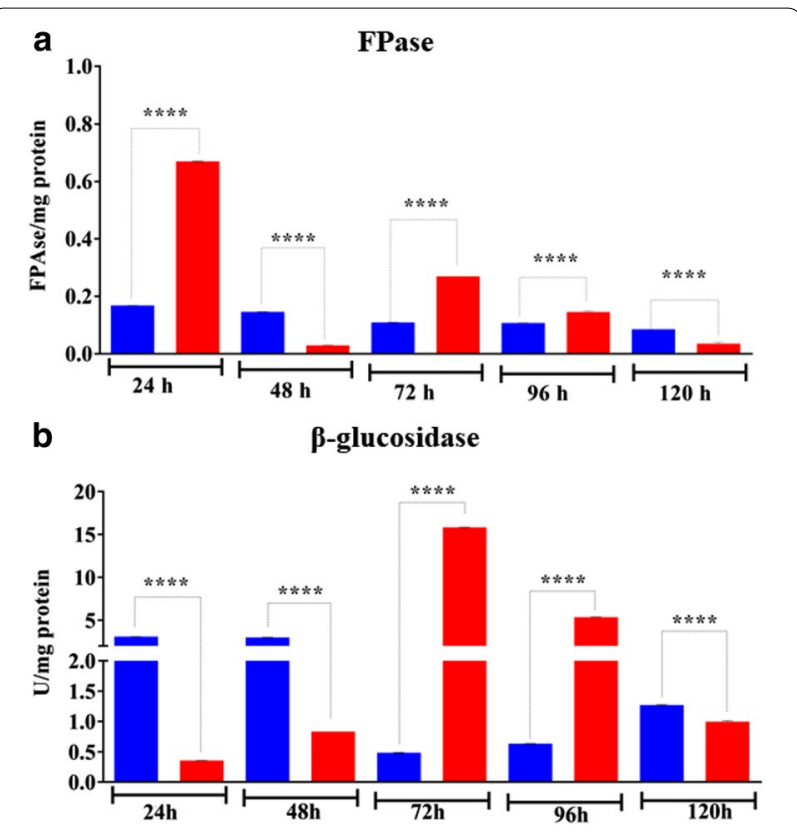

Fig. 4 Cellulolytic activities from culture supernatant and purified $T$. reesei EVs after induction in the presence of cellulose. a Filter paper activity (FPase) and $\mathbf{b} \beta$-glucosidase activity from culture supernatant (blue bars) and purified T. reesei EVs (red bars) grown at 24, 48, 72, 96 and $120 \mathrm{~h}$ in the presence of cellulose. ${ }^{* * *}$ Significantly different $(P<0.001)$. These results are based on three replicates of three independent experiments and are expressed as mean \pm standard deviation

of cellulose when compared to culture supernatant at the same time (Fig. 4a). The lowest FPase activity was detected inside vesicles from 48 to $120 \mathrm{~h}$ of cultivation in the presence of cellulose. Curiously, although our proteomic analysis was not able to identify $\beta$-glucosidase inside cellulose-purified EVs, the specific $\beta$-glucosidase activity was higher in purified EVs from 72 to $96 \mathrm{~h}$ of cultivation when compared to culture supernatant at the same time (Fig. 4b). In the same assay, cellulose-purified EVs at $24 \mathrm{~h}, 48 \mathrm{~h}$, and $120 \mathrm{~h}$ presented significantly lower $\beta$-glucosidase activity than the supernatant culture. Our enzymatic assay revealed that EVs isolated from glucose and glycerol showed almost undetectable level of cellulase activity (Additional file 1: Fig. S5). These results suggest that there is an intriguing mechanism of $\beta$-glucosidase and total cellulase enrichment inside the vesicles in the presence of cellulose.

Concomitantly, our RNA analysis revealed that there is a slight enrichment of RNA inside vesicles from 96- and $120 \mathrm{~h}$ of induction by cellulose. This content consisted mostly of EVs RNA molecules less than 200 nucleotides (Additional file 1: Fig. S2). This result suggests that $T$. reesei is able to release smalls RNAs from extracellular vesicles and these RNA-containing vesicles may be important to regulate various biological processes in this fungus.

\section{Discussion}

Previous studies with other organisms such as Saccharomyces cerevisiae [48], Cryptococcus neoformans [49] and Histoplasma capsulatum [50] revealed that fungal extracellular vesicles carry proteins with highly diverse functions. Similarly, our data revealed that the extracellular vesicles of $T$. reesei have a wide range of proteins (Additional file 2). The same way, our proteomic analyses also pointed out important findings of vesicle formation and transport in $T$. reesei in response to cellulose presence. The coat protein complex II (COPII) generates transport vesicles that mediate protein transport from the endoplasmic reticulum (ER) [17]. After synthesis, most of the secretory proteins within the endoplasmic reticulum are transported to the Golgi via COPII-coated vesicles and, the formation of COPII-coated vesicles is regulated by small GTPases [51, 52]. Then, assembly of the COPII coat is initiated through activation of the small Ras-like GTPases by ER-bound transmembrane guanine-nucleotide exchange factor (GEF), promoting the recruitment of Sec23/Sec24, an inner-coat complex component, by activated-small GTPases to form the pre-budding complex with cargo proteins $[53,54]$.

Our results demonstrated that some components involved with intracellular trafficking, secretion, and vesicular transport such as vesicle coat complex COPIISec24 and small GTPases, belonging to COPII-GTPAseSec24 secretion pathway were identified at EVs proteome in $T$. reesei in presence of cellulose. Similarly, we demonstrated that induction promoted by cellulose led to the production of EVs enriched with specific small GTPases such as IDs 80898 and 77031, which are involved in polar growth, exocytosis, endocytosis and secretory-vesicle fusion to the plasma membrane [55-57]. In addition, a vesicle-associated membrane protein (VAMP/Synaptobrevin) involved with trafficking proteins were equally identified in our data. This protein is a crucial component of trans-Golgi network (TGN)-endosomal system for vesicular transport, being responsible to the export, sorting, and recycling of numerous soluble and membraneassociated lysosomal and secretory pathway proteins [58, 59]. Interestingly, it has been shown that fungal cell wall plays an important role in the secretion process since many of the proteins secreted are structurally associated with the plasma membrane and the cell wall [60].

Furthermore, a number of cellular processes such as secretion involve the transport of intracellular membrane vesicles that may be attended by the actin cytoskeleton remodeling [55]. Here, we identified several proteins 
including actin and tubulin structural molecules associated with microtubule-based movement inside $T$. reesei EVs supporting the evidence for a vesicle trafficking under the presence of cellulose from 24 to $120 \mathrm{~h}$ of culture. These results provide evidence to a canonical mechanism of protein secretion in this fungus, involving the formation and recruitment of new proteins for constructing secretory pathways in the presence of cellulose. $T$. reesei $\mathrm{EVs}$ were also enriched with proteins involved with posttranslational modification, protein turnover, and chaperones. Among them, we identified two heat shock proteins (Hsp70 and Hsp60), a carboxypeptidase, a peptidyl-prolyl isomerase, a molecular chaperone protein with a DnaJ domain and an ER-chaperone calnexin located in the membrane of the endoplasmic reticulum to ensure the proper folding of glycoproteins [61]. These findings suggest that there is an appropriated folding process involving the formation of disulphide bond to develop the tertiary and quaternary structures of the protein to provide a proper protein secretion process in response to an inductive carbon source. Moreover, our results identified for the first time the presence of Hsp proteins inside T. reesei EVs. Hsp proteins have been suggested to be exported by an interesting mechanism mediated by the insertion of the protein into the membrane of export vesicles [62, 63]. O'Neill and Quah [64] have suggested that extracellular Hsp are likely to act as indicators of the stress conditions, priming other cells, particularly of the immune system, to avoid the propagation of the insult. Additionally, so extracellular Hsp, for instance, Hsp70, is associated with export vesicles, displaying a robust activation of macrophages [64]. Together, our results suggest that Hsp proteins associated with $T$. reesei EVs might be an additional mechanism of $T$. reesei to environmental sensing by the fungus, and future studies are required to better understand their importance in EVs and possible involved mechanisms.

About the holocellulolytic biomass degradation system of $T$. reesei, it has been shown that is one of the most studied within the filamentous fungi. This fungus has the ability to produce a high cellulase content due to the efficient capability to sense and transport nutrient for rapid induction and secretion of cellulases [32, 65-67]. However, there is a series of questions regarding the secretory pathway of cellulases that remain unanswered. Since cellulases are secreted enzymes, the control of their biosynthesis may require various steps of the secretory pathway [68]. In T. reesei, studies have shown that cellulases are resident in the endoplasmic reticulum-derived vesicles attached to the outside surface of the membrane [69]. First of all, the cellulase expression and secretion requires an induction that might include the formation of new proteins for constructing secretory pathways [70]. T. reesei secrets large amounts of extracellular cellulolytic enzymes [71, 72] which are regulated in a coordinated manner that depends on the availability of the carbon sources [32, 66, 73, 74]. However, there is an open discussion about the nature of such an inducer molecule, since cellulose is unlikely to directly trigger the cellulase induction because of its insolubility [75]. Here, we showed that in the presence of cellulose $T$. reese $i$ is able to produce a high concentration of EVs when compared to glucose and glycerol. In the presence of glucose, a readily available carbon source, the fungus can activate the mechanism of catabolite carbon repression (CCR) and inhibit the production of cellulolytic complex enzymes to avoid unnecessary energy expenditure $[6,76]$. This way, our results suggest that growth in the presence of cellulose can promote an increase in EVs production and these particles might be enriched with cellulases through an unclear mechanism yet. Our results are according to those observed in Fibrobacter succinogenes, a cellulolytic bacterium, in which it was showed that cellulose induces vesicles formation [77]. This way, our results suggest that Fibrobacter and Trichoderma might share some physiological similarities in EVs formation. However, even with these similarities, the mechanisms involved with EVs formation in both organisms might be different in various aspects. So, further experiments are necessary to fully understanding of the factors controlling EVs formation in T. reesei. At this moment, we were able to show that there is a presence of cellulase inside T. reesei EVs, and this could be involved in cellulose degradation as supported by the presence of CAZymes inside EVs as demonstrated by our proteomic analysis.

In this context, reports have suggested that there are different mechanisms underlying cellulase secretion, one specific secretory pathway independent of cellulose, another induced by cellulose, and a third one that occurs separately of the carbon source [78]. So, how would cellulose trigger the induction of cellulases? Different studies investigating this aspect postulated the induction function of a low molecular weight and soluble compound derived from cellulose [79, 80]. A hypothesis is that $T$. reesei has low levels of constitutive cellulase promoting the cellulose breakdown when it becomes available [81]. Gong and Tsao [82] and Stutzenberger [83] proposed a model for the first steps of the cellulose degradation process through the action of cellulases. These authors suggested the conidia surface contains cellobiohydrolases that degrade the cellulose into cello-oligosaccharides, which in turn may be either hydrolyzed until glucose for immediate consumption or transglycosylated to sophorose, by the action of a constitutive $\beta$-glucosidase. The sophorose obtained from the cello-oligosaccharides processing then acts as an inducer for de novo production 
and secretion of cellulases, starting a cycle where glucose and sophorose are produced until complete cellulose degradation. It was also demonstrated that the cellobiohydrolases Cel7a and Cel6a, and the endoglucanase Cel5a are constitutive of the conidia surface and, along with the $\beta$-glucosidase, these enzymes are crucial for the initiation of cellulases induction for cellulose breakdown $[84,85]$. Similarly, the existence of a constitutive $\beta$-glucosidase on the plasma membrane has also been suggested $[86,87]$. Foreman et al. [88] also suggested that CEL5B contains the consensus sequence for membrane-anchoring via a glycosylphosphatidylinositol residue which make it an interesting candidate for generating the inducer of cellulase formation. Similarly, the acetyl xylan esterase Axe2, which is also predicted to contain a glycosylphosphatidylinositol anchor, may be involved in the primary induction of some hemicellulases [88]. Therefore, we argue that $T$. reesei secrets vesicles containing cellulases that in turn releases cellobiose and glucose for cellulase induction and production, as well as glucose for fungal growth. However, as discussed above the mechanisms of induction of cellulase expression are complex and some aspects are unclear yet. Probably, there is crosstalk between different molecular mechanisms involved in cellulase formation. This way, our results brings light into how this process can trigger in T. reesei. Nevertheless, there is a still undefined role in regulated mechanisms of cellulase induction and secretion in this fungus, and future studies are required to better understand their importance in EVs and possible involved mechanisms. Furthermore, as an additional mechanism, $T$. reesei can secrete heatshock proteins since these proteins were identified in EVs indicating novel strategies of environmental sensing by the fungus.

Burnet et al. [89] showed that Fibrobacter succinogenes, an important degrader of lignocellulosic plant material in the herbivore gut is able to produce extracellular vesicles. Forsberg et al. [90] suggested the use of these vesicles in cellulose degradation. According to this author, vesicles containing cellulases are released from the outer membrane via bleb formation. They posited that these vesicles could be released into the area between the cellulose and cell. Additionally, they demonstrated vesicles adhering to cellulose and vesicles either attached to the outer membrane or in the extracellular medium, but only in the stationary cultures. Also, is suggested that the use of vesicles during stationary phase may act as a delivery mechanism for a concentrated cocktail of cellulases to actively degrade cellulose at the site of attachment [90]. This way, cellulose is degraded and, the resulting cellodextrins would be transported into the cell for further breakdown. When attached cells reach stationary phase, the outer membrane blebs of and forms vesicles in order to continue cellulose degradation in a nutritionally limited environment [91]. These findings are consistent with a previous report showing that the presence of cellulose induces vesicles formation [77].

Likewise, Arntzen et al. [92] showed that OMVs (Outer Membrane Vesicles) produced by $F$. succinogenes are equipped with a diverse suite of enzymes able to depolymerize most common plant polysaccharides, including cellulose. Moreover, OMVs might assist the metabolism of the host cell by deconstructing non-essential polysaccharides that restrict access to the host's target carbon source [92]. Finally, in F. succinogenes, cellulose binding proteins are arranged in novel putative complexes in OMVs, suggesting that this bacterium degrades biomass using means that differ fundamentally from well-known degradative machinery in nature. As proposed by F. succinogenes, T. reesei can use EVs to secrete cellulases to make the process of cellulose degradation more efficiently. Moreover, the production of EVs enriched with CAZymes might be in response to an inductive carbon source as proposed by [77], contributing to a favorable process of the economy of energy.

Recently, it was demonstrated that plants packages small RNAs in extracellular vesicles directed to fungal pathogens to silence virulence genes [93], showing that plant extracellular vesicles (mainly exosomes) have a crucial role in cross-kingdom sRNA trafficking between Arabidopsis and the fungal pathogen Botrytis cinerea. Likewise, the human pathogens $C$. neoformans, Paracoccidioides brasiliensis, and Candida albicans, and the model yeast $S$. cerevisiae can accumulate small RNAs inside extracellular vesicles [37]. Also, in H. capsulatum, EVs carry RNA-binding proteins, as well as mRNAs and non-coding RNAs [94]. The process of RNA export mediated by EVs have been discussed as a universal mechanism for inter-kingdom and intra-kingdom communication [95], and it is reasonable to suggest that RNAs transported by fungal EVs might play important role in cell communication [96]. Since EVs were reported involved in reverted avirulent phenotype by mechanisms vesicular RNA dependent in Cryptococcus gattii [97], it is also reasonable to suggest that enrichment of small RNAs in the EVs 96- and $120 \mathrm{~h}$ in T. reesei, might have a still undefined role in regulated mechanisms of gene expression in this fungus, and future studies are required to better understand their importance in EVs and possible involved mechanisms.

The presence of numerous secretion pathways in filamentous fungi might provide information about their high secretory capacity. Nevertheless, the molecular machinery for protein secretion in filamentous fungi remains mostly unknown [98]. There are many unclear issues regarding fungal EVs biosynthesis and unloading. 
Thus, to understand the biological functions of fungal EVs should reveal important roles of EVs in several biological processes [96]. Galectin-3, a mammalian $\beta$-galactoside-binding protein, has been reported playing disruption and internalization of EVs produced from $C$. neoformans [35] and P. brasiliensis [99] by macrophages. However, additional studies are needed to discern how EVs deliver their cargo, as well as to identify new molecules playing a lytic effect on fungal EVs. Briefly, our data showed the first characterization and proteomic analysis of T. reesei EVs in the presence of cellulose. Here, we present some new evidence supporting that the secretory pathway from $T$. reesei has the basic machinery for vesicle trafficking, similar to other filamentous fungi and eukaryotes. In initial signaling in presence of cellulose, $T$. reesei secretes a great number of vesicles enriched with cellulases and heat shock proteins (Hsps) to breakdown the cellulose polymer and, for carbon source recognition and environmental sensing, respectively. Then, cellobiose released after cellulose degradation can be both cleaved to glucose or transglycosylated to form sophorose. In turn, glucose may be used for fungal growth while cellobiose and sophorose may induce the cellulase expression by regulation of the main transcription factors involved with the control of cellulase expression. Finally, the synthesized cellulases might be packaging in vesicles and released to an environment to ensure cellulose breakdown. The data open new approach in order to generate mutants to increase biomass degradation.

\section{Conclusions}

Currently, the filamentous fungi $T$. reesei have been established as the most important holocellulase producer used by biotechnology industries. Thus, genomics, transcriptomics, proteomics, and secretomics analyses have been employed as excellent approaches to the better understanding of mechanisms involved with cellulase gene expression and secretion in this fungus. This way, knowledge about the mechanisms involved in the recognition of environmental signals is extremely important in fungal biology comprehension. In conclusion, our study brings new insights about the cellulase secretion in $T$. reesei and suggests that there are additional secretory pathways involved in cellulase secretion in this fungus since a few numbers of cellulases were found associated with cellulose-purified EVs.

\section{Additional files}

Additional file 1: Fig. S1. Characterization of Trichoderma reesei EVs. Mean size distribution by Nanoparticle Tracking Analysis (NTA) of purified T. reesei EVs from the cellulose-supernatant culture at 24, 48, 72, 96 and $120 \mathrm{~h}$.
These results are based on three replicates of three independent experiments. Fig. S2. Bioanalyzer profile of the RNA content of EVs from the $T$. reesei fungus grown at 24,72,96 and $120 \mathrm{~h}$ in the presence of cellulose. Fig. S3. Characterization of Trichoderma reesei EVs. Mean size distribution by Nanoparticle Tracking Analysis (NTA) of purified T. reesei EVs from glycerol (a), glucose (b), and both conditions (c) at $24 \mathrm{~h}$. These results are based on three replicates of three independent experiments. Fig. S4 TEM analyses of vesicles in Trichoderma reesei mycelium cells. The occurrence of vesicles in association with the cytoplasmic membrane and cell wall is evident after growth for $24 \mathrm{~h}$ in the presence of glucose and glycerol. Black arrows indicate the CW (cell wall) and CM (cell membrane). Red arrows indicate the T. reesei vesicles. Bars, $500 \mathrm{~nm}$ and $200 \mathrm{~nm}$. Fig. S5 Cellulolytic activities from purified $T$. reesei EVs after growth in the presence of cellulose, glycerol and glucose. (a) Filter paper activity (FPase) and (b) $\beta$-glucosidase activity from purified T. reesei EVs grown at $24 \mathrm{~h}$ in the presence of respective carbon source. ${ }^{* * *}=$ Significantly different $(P<0.001)$. These results are based on three replicates of three independent experiments and are expressed as mean \pm standard deviation.

Additional file 2. List of vesicular proteins identified in T. reesei EVs in the presence of cellulose.

\section{Abbreviations}

EVs: extracellular vesicles; ER: endoplasmic reticulum; MEX: malt extract; NTA: nanoparticle-tracking analysis; TEM: transmission electron microscopy; PNPG: p-nitrophenyl- $\beta$-D-glucopyranoside; FPase: filter paper activity; CM: cytoplasmic membrane; CW: cell wall; KOG: EuKaryotic Orthologous Groups; CAZy: Carbohydrate-Active enZYmes.

\section{Acknowledgements}

We are thankful to Professor Astrid Mach-Aigner from TU-Wien for providing the QM6a $\triangle$ mus $53 \Delta$ pyr4 strain used in this study, Maria D. Seabra Ferreira (Laboratório de Microscopia Eletrônica, Departamento de Biologia Celular e Molecular e Bioagentes Patogênicos, Faculdade de Medicina de Ribeirão Preto) for the microscopy sample preparations and Centro de Caracterização e Desenvolvimento de Protocolos em Nanotecnologia (Instituto de QuímicaUNESP-Araraquara) for acquisition of images. We also would like to thank Vania Blasques Bueno (Analytical Center of Institute of Chemistry-USP) to assist us in performing mass spectrometry analysis.

\section{Authors' contributions}

RNS and RGP conceived and designed the experiments. RGP performed T. reesei manipulation, vesicles experiments, proteomic analysis, enzymatic assays, interpreted results and wrote the manuscript. ACCA, IM and MCR performed and interpreted TEM. KMVN performed enzymatic assays. LFCR performed proteomic sample preparations. FA interpreted the vesicles analysis. All authors read and approved the final manuscript.

\section{Funding}

This work was supported by Coordination of Superior Level Staff Improvement (CAPES) and the State of São Paulo Research Foundation (FAPESP) (proc. 2016/23233-9 and 2017/04206-3).

\section{Availability of data and materials}

All data supporting our findings can be found in Additional files 1 and 2, which have been provided as additional materials.

\section{Ethics approval and consent to participate}

Not applicable.

Consent for publication

Not applicable.

\section{Competing interests}

The authors declare that they have no competing interests.

\section{Author details}

${ }^{1}$ Department of Biochemistry and Immunology, Ribeirao Preto Medical School, University of Sao Paulo, Ribeirao Preto, São Paulo 14049-900, Brazil. 
${ }^{2}$ Departamento de Genética e Evolução, Centro de Ciências Biológicas e da Saúde, Universidade Federal de São Carlos, São Paulo, Brazil.

Received: 19 December 2018 Accepted: 7 June 2019

Published online: 15 June 2019

\section{References}

1. Bischof RH, Ramoni J, Seiboth B. Cellulases and beyond: the first 70 years of the enzyme producer Trichoderma reesei. Microb Cell Fact. 2016;15:1-13.

2. Li Y, LiU C, Bai F, Zhao X. Overproduction of cellulase by Trichoderma reesei RUT C30 through batch-feeding of synthesized low-cost sugar mixture. Bioresour Technol. 2016;216:503-10.

3. Huang J, Chen D, Wei Y, Wang Q, Li Z, Chen Y, et al. Direct ethanol production from lignocellulosic sugars and sugarcane bagasse by a recombinant Trichoderma reesei strain hj48. Sci World J. 2014. https://doi. org/10.1155/2014/798683.

4. Adav SS, Sze SK. Trichoderma secretome: an overview. In: Gupta VK, Schmoll M, Herrera-Estrella A, Upadhyay RS, Druzhinina I, Tuohy MG, editors. Biotechnology and biology of Trichoderma. 1st ed. Waltham: Elsevier; 2014. p. 103-14.

5. Samuels GJ. Trichoderma: a review of biology and systematics of the genus. Mycol Res. 1996;100:923-35.

6. Gupta VK, Steindorff AS, de Paula RG, Silva-Rocha R, Mach-Aigner AR, Mach RL, et al. The post-genomic era of Trichoderma reesei: what's next? Trends Biotechnol. 2016;34:970-82.

7. Harman GE, Herrera-Estrella AH, Horwitz BA, Lorito M. Special issue: Trichoderma-from basic biology to biotechnology. Microbiology. 2012;158:1-2

8. Schuster A, Schmoll M. Biology and biotechnology of Trichoderma. Appl Microbiol Biotechnol. 2010:87:787-99.

9. Kubicek CP, Komon-Zelazowska M, Druzhinina IS. Fungal genus Hypocrea/Trichoderma: from barcodes to biodiversity. J Zhejiang Univ Sci B. 2008;9:753-63.

10. Bazafkan H, Tisch D, Schmoll M. Regulation of glycoside hydrolase expression in Trichoderma. In: Gupta VK, Schmoll M, Herrera-Estrella A Upadhyay R, Druzhinina I, Tuohy MG, editors. Biotechnology and biology of Trichoderma. Amsterdam: Elsevier; 2014. p. 527.

11. Saloheimo M, Pakula T, Aro N, Joensuu J. Protein production - quality control and secretion stress responses in Trichoderma reesei. In: Gupta VK, Schmoll M, Herrera-Estrella A, Upadhyay R, Druzhinina I, Tuohy MG, editors. Biotechnology and biology of Trichoderma. Amsterdam: Elsevier; 2014

12. Hernández-Chávez M, González-Hernández R, Trujillo-Esquivel f Hernández-Cervantes A, Mora-Montes H. The secretory pathway in the filamentous fungus Trichoderma. In: Gupta VK, Schmoll M, Herrera-Estrella A, Upadhyay R, Druzhinina I, Tuohy MG, editors. Biotechnology and biology of Trichoderma. Amsterdam: Elsevier; 2014.

13. Aebi M, Bernasconi R, Clerc S, Molinari M. N-glycan structures: recognition and processing in the ER. Trends Biochem Sci. 2010;35:74-82.

14. Kottmeier K, Ostermann K, Bley T, Rödel G. Hydrophobin signal sequence mediates efficient secretion of recombinant proteins in Pichia pastoris. Appl Microbiol Biotechnol. 2011;91:133-41.

15. Antonin W, Meyer H-A, Hartmann E. Interactions between Spc2p and other components of the endoplasmic reticulum translocation sites of the yeast Saccharomyces cerevisiae. J Biol Chem. 2000;275:34068-72.

16. Bonifacino JS, Glick BS. The mechanisms of vesicle budding and fusion. Cell. 2004;116:153-66

17. Sato K, Nakano A. Mechanisms of COPII vesicle formation and protein sorting. FEBS Lett. 2007:581:2076-82

18. Cai H, Reinisch K, Ferro-Novick S. Coats, tethers, Rabs, and SNAREs work together to mediate the intracellular destination of a transport vesicle. Dev Cell. 2007;12:671-82.

19. Zhou A, Webb G, Zhu X, Steiner DF. Proteolytic processing in the secretory pathway. J Biol Chem. 1999;274:20745-8.

20. van Niel G, D'Angelo G, Raposo G. Shedding light on the cell biology of extracellular vesicles. Nat Rev Mol Cell Biol. 2018;19:213-28.
21. Wang C-W, Hamamoto S, Orci L, Schekman R. Exomer: a coat complex for transport of select membrane proteins from the trans-Golgi network to the plasma membrane in yeast. J Cell Biol. 2006;174:973-83.

22. Novick P, Guo W. Ras family therapy: Rab, Rho and Ral talk to the exocyst. Trends Cell Biol. 2002:12:247-9.

23. Brennwald P, Rossi G. Spatial regulation of exocytosis and cell polarity: yeast as a model for animal cells. FEBS Lett. 2007:581:2119-24.

24. Jahn R, Scheller RH. SNAREs_-engines for membrane fusion. Nat Rev Mol Cell Biol. 2006:7:631-43.

25. Valkonen M, Kalkman ER, Saloheimo M, Penttilä M, Read ND, Duncan RR. Spatially segregated SNARE protein interactions in living fungal cells. J Biol Chem. 2007;282:22775-85.

26. Druzhinina IS, Shelest E, Kubicek CP. Novel traits of Trichoderma predicted through the analysis of its secretome. FEMS Microbiol Lett. 2012;337:1-9.

27. Adav SS, Ravindran A, Chao LT, Tan L, Singh S, Sze SK. Proteomic analysis of $\mathrm{pH}$ and strains dependent protein secretion of Trichoderma reesei. J Proteome Res. 2011;10:4579-96.

28. Jun $\mathrm{H}$, Kieselbach $\mathrm{T}$, Jönsson $L$ J. Enzyme production by filamentous fungi: analysis of the secretome of Trichoderma reesei grown on unconventional carbon source. Microb Cell Fact. 2011;10:68.

29. Druzhinina IS, Kubicek CP. Genetic engineering of Trichoderma reesei cellulases and their production. Microb Biotechnol. 2017;10:1485-99.

30. Derntl C, Kiesenhofer DP, Mach RL, Mach-Aigner AR. Novel strategies for genomic manipulation of Trichoderma reesei with the purpose of strain engineering. Appl Environ Microbiol. 2015;81:6314-23.

31. Schmoll M, Schuster A, Silva Rdo N, Kubicek CP. The G-alpha protein GNA3 of Hypocrea jecorina (Anamorph Trichoderma reesei) regulates cellulase gene expression in the presence of light. Eukaryot Cell. 2009:8:410-20

32. Castro LS, De Paula RG, Antonieto ACC, Gabriela F, Silva-rocha R, Silva RN. Understanding the role of the master regulator XYR1 in Trichoderma reese by global transcriptional analysis. Front Microbiol. 2016;7:175.

33. de Paula RG, Antoniêto ACC, Carraro CB, Lopes DCB, Persinoti GF, Peres NTA, et al. The duality of the MAPK signaling pathway in the control of metabolic processes and cellulase production in Trichoderma reesei. Sci Rep. 2018:8:14931.

34. Rodrigues ML, Nimrichter L, Oliveira DL, Frases S, Miranda K, Zaragoza $\mathrm{O}$, et al. Vesicular polysaccharide export in Cryptococcus neoformans is a eukaryotic solution to the problem of fungal trans-cell wall transport. Eukaryot Cell. 2007;6:48-59.

35. Almeida F, Wolf JM, da Silva TA, DeLeon-Rodriguez CM, Rezende CP, Pessoni AM, et al. Galectin-3 impacts Cryptococcus neoformans infection through direct antifungal effects. Nat Commun. 2017;8:1968.

36. da Silva TA, Roque-Barreira MC, Casadevall A, Almeida F. Extracellular vesicles from Paracoccidioides brasiliensis induced M1 polarization in vitro. Sci Rep. 2016:6:35867.

37. Peres da Silva R, Puccia R, Rodrigues ML, Oliveira DL, Joffe LS, César $\mathrm{GV}$, et al. Extracellular vesicle-mediated export of fungal RNA. Sci Rep. 2015:5:7763.

38. Bitencourt TA, Rezende CP, Quaresemin NR, Moreno P, Hatanaka O, Rossi A, et al. Extracellular vesicles from the dermatophyte Trichophyton interdigitale modulate macrophage and keratinocyte functions. Front Immunol. 2018.9.2343.

39. Silva BMA, Prados-Rosales R, Espadas-Moreno J, Wolf JM, Luque-Garcia $\mathrm{JL}$, Gonçalves T, et al. Characterization of Alternaria infectoria extracellular vesicles. Med Mycol. 2014;52:202-10. https://doi.org/10.1093/mmy/ myt003.

40. MacLean B, Eng JK, Beavis RC, McIntosh M. General framework for developing and evaluating database scoring algorithms using the TANDEM search engine. Bioinformatics. 2006;22:2830-2.

41. Keller A, Nesvizhskii Al, Kolker E, Aebersold R. Empirical statistical model to estimate the accuracy of peptide identifications made by MS/MS and database search. Anal Chem. 2002;74:5383-92.

42. Nesvizhskii Al, Keller A, Kolker E, Aebersold R. A statistical model for identifying proteins by tandem mass spectrometry. Anal Chem. 2003;75:4646-58

43. dos Santos Castro S, Antoniêto ACC, Pedersoli WR, Silva-Rocha R, Persinoti GF, Silva RN. Expression pattern of cellulolytic and xylanolytic genes regulated by transcriptional factors XYR1 and CRE1 are affected by carbon source in Trichoderma reesei. Gene Expr Patterns. 2014;14:88-95. 
44. Hideno A, Inoue H, Tsukahara K, Yano S, Fang X, Endo T, et al. Production and characterization of cellulases and hemicellulases by Acremonium cellulolyticus using rice straw subjected to various pretreatments as the carbon source. Enzyme Microb Technol. 2011;48:162-8.

45. Lopes FAC, Steindorff AS, Geraldine AM, Brandão RS, Monteiro VN, Lobo $\mathrm{M}$, et al. Biochemical and metabolic profiles of Trichoderma strains isolated from common bean crops in the Brazilian Cerrado, and potential antagonism against Sclerotinia sclerotiorum. Fungal Biol. 2012;116:815-24.

46. Wang M, Zhao Q, Yang J, Jiang B, Wang F, Liu K, et al. A mitogen-activated protein kinase Tmk3 participates in high osmolarity resistance, cell wall integrity maintenance and cellulase production regulation in Trichoderma reesei. PLoS ONE. 2013;8:e72189.

47. Antoniêto ACC, Ramos Pedersoli W, dos Santos Castro L, da Silva Santos R, Silva Cruz AH, Nogueira KMV, et al. Deletion of $\mathrm{pH}$ regulator pac-3 affects cellulase and xylanase activity during sugarcane bagasse degradation by Neurospora crassa. PLoS ONE. 2017;12:e0169796.

48. Oliveira DL, Nakayasu ES, Joffe LS, Guimarães AJ, Sobreira TJP, Nosanchuk $J \mathrm{D}$, et al. Characterization of yeast extracellular vesicles: evidence for the participation of different pathways of cellular traffic in vesicle biogenesis. PLoS ONE. 2010:5:e11113. https://doi.org/10.1371/journal.pone.0011113.

49. Rodrigues ML, Nakayasu ES, Oliveira DL, Nimrichter L, Nosanchuk JD, Almeida IC, et al. Extracellular vesicles produced by Cryptococcus neoformans contain protein components associated with virulence. Eukaryot Cell. 2008;7:58-67.

50. Albuquerque PC, Nakayasu ES, Rodrigues ML, Frases S, Casadevall A, Zancope-Oliveira RM, et al. Vesicular transport in Histoplasma capsulatum: an effective mechanism for trans-cell wall transfer of proteins and lipids in ascomycetes. Cell Microbiol. 2008;10:1695-710. https://doi.org/10.111 1/j.1462-5822.2008.01160.x

51. D'Arcangelo JG, Stahmer KR, Miller EA. Vesicle-mediated export from the ER: COPII coat function and regulation. Biochim Biophys Acta Mol Cell Res. 2013;1833:2464-72.

52. Saito K, Maeda M, Katada T. Regulation of the Sar1 GTPase cycle is necessary for large cargo secretion from the endoplasmic reticulum. Front Cell Dev Biol. 2017;5:75.

53. Barlowe C, Schekman R. SEC12 encodes a guanine-nucleotide-exchange factor essential for transport vesicle budding from the ER. Nature. 1993;365:347-9. https://doi.org/10.1038/365347a0.

54. Miller EA, Beilharz TH, Malkus PN, Lee MCS, Hamamoto S, Orci L, et al. Multiple cargo binding sites on the COPII subunit Sec24p ensure capture of diverse membrane proteins into transport vesicles. Cell. 2003:114:497-509.

55. Van Aelst L, D'Souza-Schorey C. Rho GTPases and signaling networks. Genes Dev. 1997;11:2295-322.

56. Johnson DI. Cdc42: an essential Rho-type GTPase controlling eukaryotic cell polarity. Microbiol Mol Biol Rev. 1999;63:54-105.

57. de Oliveira JMPF, van Passel MWJ, Schaap PJ, de Graaff LH. Shotgun proteomics of Aspergillus niger microsomes upon D-xylose induction. Appl Environ Microbiol. 2010;76:4421-9.

58. Steegmaier M, Klumperman J, Foletti DL, Yoo JS, Scheller RH. Vesicle-associated membrane protein 4 is implicated in trans-Golgi network vesicle trafficking. Mol Biol Cell. 1999;10:1957-72.

59. Chaineau M, Danglot L, Galli T. Multiple roles of the vesicular-SNARE TIVAMP in post-Golgi and endosomal trafficking. FEBS Lett. 2009;583:381726. https://doi.org/10.1016/j.febslet.2009.10.026.

60. Peberdy JF. Protein secretion in filamentous fungi-trying to understand a highly productive black box. Trends Biotechnol. 1994;12:50-7.

61. Lamriben L, Graham JB, Adams BM, Hebert DN. N-glycan-based ER molecular chaperone and protein quality control system: the calnexin binding cycle. Traffic. 2016;17:308-26. https://doi.org/10.1111/tra.12358.

62. Vega VL, Rodríguez-Silva M, Frey T, Gehrmann M, Diaz JC, Steinem C, et al. Hsp70 translocates into the plasma membrane after stress and is released into the extracellular environment in a membrane-associated form that activates macrophages. J Immunol. 2008;180:4299-307.

63. De Maio A. Extracellular heat shock proteins, cellular export vesicles, and the Stress Observation System: a form of communication during injury, infection, and cell damage. It is never known how far a controversial finding will go! Dedicated to Ferruccio Ritossa. Cell Stress Chaperones. 2011;16:235-49.

64. O'Neill HC, Quah BJC. Exosomes secreted by bacterially infected macrophages are proinflammatory. Sci Signal. 2008;1:pe8.
65. dos Santos Castro L, Pedersoli WR, Antoniêto ACC, Steindorff AS, SilvaRocha R, Martinez-Rossi NM, et al. Comparative metabolism of cellulose, sophorose and glucose in Trichoderma reesei using high-throughput genomic and proteomic analyses. Biotechnol Biofuels. 2014;7:41.

66. de Paula RG, Antoniêto ACC, Ribeiro LFC, Carraro CB, Nogueira KMV, Lopes DCB, et al. New genomic approaches to enhance biomass degradation by the industrial fungus Trichoderma reesei. Int J Genom. 2018;2018:1-17.

67. Schmoll M, Dattenböck C, Carreras-Villaseñor N, Mendoza-Mendoza A, Tisch D, Alemán Ml, et al. The genomes of three uneven siblings: footprints of the lifestyles of three Trichoderma Species. Microbiol Mol Biol Rev. 2016:80:205-327.

68. Kubicek CP, Messner R, Gruber F, Mach RL, Kubicek-Pranz EM. The Trichoderma cellulase regulatory puzzle: from the interior life of a secretory fungus. Enzym Microb Technol. 1993;15:90-9.

69. Glenn M, Ghosh A, Ghosh BK. Subcellular fractionation of a hypercellulolytic mutant, Trichoderma reesei Rut-C30: localization of endoglucanase in microsomal fraction. Appl Environ Microbiol. 1985;50:1137-43.

70. Yan S, Wu G. Secretory pathway of cellulase: a mini-review. Biotechnol Biofuels. 2013;6:177.

71. Song X, Wang Y, Zhang S, Yan S, Li T, Yao L. Characterization of the dielectric constant in the Trichoderma reesei Cel7B active site. J Chem Inf Model. 2015;55:1369-76.

72. Treebupachatsakul T, Shioya K, Nakazawa H, Kawaguchi T, Morikawa Y, Shida $Y$, et al. Utilization of recombinant Trichoderma reesei expressing Aspergillus aculeatus beta-glucosidase I (JN11) for a more economical production of ethanol from lignocellulosic biomass. J Biosci Bioeng. 2015;120:657-65

73. Dashtban M, Buchkowski R, Qin W. Effect of different carbon sources on cellulase production by Hypocrea jecorina (Trichoderma reesei) strains. Int J Biochem Mol Biol. 2011;2:274-86.

74. Amore A, Giacobbe S, Faraco V. Regulation of cellulase and hemicellulase gene expression in fungi. Curr Genomics. 2013;14:230-49.

75. Suto M, Tomita F. Induction and catabolite repression mechanisms of cellulase in fungi. J Biosci Bioeng. 2001;92:305-11.

76. Antoniêto ACC, de Paula RG, Dos Castro Santos L, Silva-Rocha R, Persinoti GF, Silva RN. Trichoderma reesei CRE1-mediated carbon catabolite repression in response to sophorose through RNA sequencing analysis. Curr Genomics. 2016;17:119-31.

77. Gaudet G, Gaillard B. Vesicle formation and cellulose degradation in Bacteroides succinogenes cultures: ultrastructural aspects. Arch Microbiol. 1987;148:150-4

78. McGavin M, Lam J, Forsberg CW. Regulation and distribution of Fibrobacter succinogenes subsp. succinogenes $\mathbf{5} 85$ endoglucanases. Appl Environ Microbiol. 1990:56:1235-44.

79. El-Gogary S, Leite A, Crivellaro O, Eveleigh DE, El-Dorry H. Mechanism by which cellulose triggers cellobiohydrolase I gene expression in Trichoderma reesei. Proc Natl Acad Sci USA. 1989:86:6138-41.

80. Carle-Urioste JC, Escobar-Vera J, El-Gogary S, Henrique-Silva F, Torigoi E, Crivellaro $\mathrm{O}$, et al. Cellulase induction in Trichoderma reesei by cellulose requires its own basal expression. J Biol Chem. 1997;272:10169-74.

81. Gritzali M, Brown R. The cellulase systems of Trichoderma: relationships between purified extracellular enzymes from induced or cellulosegrown cells. Adv Chem. 1979;181:237-60.

82. Gong C-S, Tsao GT. Cellulase and biosynthesis regulation. Annu Rep Ferment Process. 1979;3:111-40.

83. Stutzenberger F. Regulation of cellulolytic activity. Annu Rep Ferment Process. 1985;8:111-54.

84. Messner R, Kubicek-Pranz EM, Gsur A, Kubicek CP. Cellobiohydrolase I is the main conidial-bound cellulase in Trichoderma reesei and other Trichoderma strains. Arch Microbiol. 1991;155:601-6.

85. Seiboth B, Hakola S, Mach RL, Suominen PL, Kubicek CP. Role of four major cellulases in triggering of cellulase gene expression by cellulose in Trichoderma reesei. J Bacteriol. 1997;179:5318-20.

86. Umile C, Kubicek C. A constitutive, plasma-membrane bound betaglucosidase in Trichoderma reesei. FEMS Microbiol Lett. 1986;34:291-5.

87. Kubicek CP. Involvement of a conidial endoglucanase and a plasmamembrane-bound beta-glucosidase in the induction of endoglucanase synthesis by cellulose in Trichoderma reesei. J Gen Microbiol. 1987:133:1481-7. 
88. Foreman PK, Brown D, Dankmeyer L, Dean R, Diener S, DunnColeman NS, et al. Transcriptional regulation of biomass-degrading enzymes in the filamentous fungus Trichoderma reesei. J Biol Chem. 2003;278:31988-97.

89. Burnet MC, Dohnalkova AC, Neumann AP, Lipton MS, Smith RD, Suen G, et al. Evaluating models of cellulose degradation by Fibrobacter succinogenes S85. PLoS ONE. 2015;10:e0143809.

90. Forsberg CW, Beveridge TJ, Hellstrom A. Cellulase and xylanase release from Bacteroides succinogenes and its importance in the rumen environment. Appl Environ Microbiol. 1981;42:886-96.

91. Beveridge TJ. Structures of gram-negative cell walls and their derived membrane vesicles. J Bacteriol. 1999;181:4725-33.

92. Arntzen M $\varnothing$, Várnai A, Mackie RI, Eijsink VGH, Pope PB. Outer membrane vesicles from Fibrobacter succinogenes $\mathrm{S} 85$ contain an array of carbohydrate-active enzymes with versatile polysaccharide-degrading capacity. Environ Microbiol. 2017;19:2701-14.

93. Cai Q, Qiao L, Wang M, He B, Lin F-M, Palmquist J, et al. Plants send small RNAs in extracellular vesicles to fungal pathogen to silence virulence genes. Science. 2018;360:1126-9. https://doi.org/10.1126/science.aar41 42.

94. Alves LR, Silva RP da, Sanchez DA, Zamith-Miranda D, Rodrigues ML, Goldenberg $\mathrm{S}$, et al. Extracellular vesicle-mediated RNA release in Histoplasma capsulatum. bioRxiv. Cold Spring Harbor Laboratory; 2019;570291.
95. Tsatsaronis JA, Franch-Arroyo S, Resch U, Charpentier E. Extracellular vesicle RNA: a universal mediator of microbial communication? Trends Microbiol. 2018;26:401-10.

96. Rodrigues ML, Casadevall A. A two-way road: novel roles for fungal extracellular vesicles. Mol Microbiol. 2018;110:11-5.

97. Bielska E, Sisquella MA, Aldeieg M, Birch C, O'Donoghue EJ, May RC. Pathogen-derived extracellular vesicles mediate virulence in the fatal human pathogen Cryptococcus gattii. Nat Commun. 2018;9:1556.

98. Valkonen M. Functional studies of the secretory pathway of filamentous fungi. The effect of unfolded protein response on protein production. Helsinki: VTT Publ; 2003. p. 505.

99. Hatanaka O, Rezende CP, Moreno P, Freitas Fernandes F, Oliveira Brito PKM, Martinez R, et al. Galectin-3 inhibits Paracoccidioides brasiliensis growth and impacts paracoccidioidomycosis through multiple mechanisms. mSphere. 2019;4:e00209-19.

\section{Publisher's Note}

Springer Nature remains neutral with regard to jurisdictional claims in published maps and institutional affiliations.
Ready to submit your research? Choose BMC and benefit from:

- fast, convenient online submission

- thorough peer review by experienced researchers in your field

- rapid publication on acceptance

- support for research data, including large and complex data types

- gold Open Access which fosters wider collaboration and increased citations

- maximum visibility for your research: over $100 \mathrm{M}$ website views per year

At BMC, research is always in progress.

Learn more biomedcentral.com/submissions 